\title{
REFLEXÕES HISTÓRICO-DISCURSIVAS SOBRE O MIGRANTE NUM JORNAL DE 1954
}

\section{HISTORICAL-DISCURSIVE REFLECTIONS ON THE MIGRANT IN A 1954 NEWSPAPER}

Yasmin Carolyne Soares Barreto ${ }^{1}$

Marcos L.S. Góis ${ }^{2}$

\begin{abstract}
RESUMO: Este texto apresenta resultados de uma pesquisa que mapeou e analisou um periódico jornalístico brasileiro, da regiăo sul de Mato Grosso do Sul. Para isso, elegeuse como suporte o jornal O Progresso, digitalizado pelo Centro de Documentaçáo Regional da Universidade Federal da Grande Dourados, limitando-se à década de 1950. Para a composiçáo deste texto, selecionou-se um acontecimento histórico: a Colônia Agrícola Nacional de Dourados, por sua importância no que diz respeito às políticas de colonizaçáo de Getúlio Vargas. Pela reportagem, buscou-se compreender como o jornal constrói discursivamente o "migrante" que, na época, se deslocava de outras partes do Brasil e do mundo para fixar-se nessa regiăo. Para dar conta da materialidade discursiva, este artigo mobilizou fundamentos teóricos e metodológicos dos Estudos do Discurso, principalmente aqueles centrados no construto teórico de Michel Foucault, concluindo que a matéria analisada apresenta traços linguístico-discursivos e histórico-sociais que, ainda hoje, ecoam quando se fala do sujeito "migrante".
\end{abstract}

PALAVRAS-CHAVE: Estudos do Discurso. Mídia. Migraçăo.

\begin{abstract}
This text presents results of an investigation that mapped and analyzed a Brazilian newspaper from the southern region of the state of Mato Grosso do Sul. For this purpose, the newspaper O Progresso was chosen and was scanned by the Regional Documentation Center of the Federal University of Grande Dourados, during the 1950s. For the composition of this text, a historical event was selected: the National Agricultural Colony of Dourados because of its importance with regard to president Getúlio Vargas' colonization policies. Through the report, we tried to understand how the newspaper discursively constructs the "migrant" who, at the time, moved from other parts of Brazil and from the world to settle down in that region. In order to account for discourse materiality, this article counts on theoretical and methodological foundations of Discourse Studies, especially those centered on Michel Foucault's theoretical construct, concluding that the analyzed subject has linguistic-discursive and historical-social traits that still echo when we talk about the "migrant" person.
\end{abstract}

KEYWORDS: Discourse Studies. Media. Migration.

1 Graduanda em Letras. 2017. Faculdade de Comunicaçăo, Artes e Letras. Universidade Federal da Grande Dourados. Bolsista CNPq.de Iniciaçăo Científica. E-mail: ycarollyne79@gmail.com

2 Doutor em Linguística e Língua Portuguesa pela Unesp de Araraquara. Professor Associado da Faculdade de Comunicaçâo, Artes e Letras. Universidade Federal da Grande Dourados. E-mail: marcosgois@ufgd.edu.br 


\section{NOTAS DE INTRODUÇÃO}

Este artigo é resultado de um ano de trabalho. Nele, expomos parte do resultado de pesquisa da autora principal, que buscou compreender como o jornal 0 progresso ajudou a construir certa perspectiva de identidade sul-mato-grossense ou, precisamente, douradense. Na investigaçăo, foi fundamental, por sua relevância sócio-histórica, tratar do sujeito "migrante", figura de relevo que, se deslocando de outras regióes do Brasil e do mundo, chegou ao sul do entăo Mato Grosso para construir aí o seu lugar. A importância desse jornal na formaçăo de certa identidade douradense e sul-mato-grossense é significativa a ponto de "O slogan do jornal "pensamento e açâo por uma vida melhor" reafirma[r] a autoridade da imprensa no que se refere ao pensar (pensamento) em uma vida melhor. Além de refletir e formar uma opiniăo pública, o jornal de Weimar Torres se propunha a agir" (ERNANDES, 2009, p. 61-62, grifos do autor).

A partir de uma pesquisa bibliográfica e documental, mobilizando-se aportes teóricos e metodológicos dos Estudos do Discurso e da Historiografia para tratamento de um acontecimento histórico-discursivo específico - Colônia Agrícola Nacional de Dourados -, o corpus foi construído pela leitura e análise de matérias publicadas entre os anos 1951 e 1960 pelo O progresso, disponibilizadas no banco de dados do Centro de Divulgaçăo Regional (CDR), ligado à Universidade Federal da Grande Dourados, responsável pela digitalizaçăo desse periódico douradense. Especificamente para este trabalho, destacamos e analisamos uma matéria publicada no ano de 1954 que trata do acontecimento "Colônia Agrícola Nacional de Dourados" (CAND), por seu valor social e histórico no que diz respeito às políticas de interiorizaçăo de Getúlio Vargas.

O trabalho está dividido em duas partes gerais: na primeira, fazemos uma breve contextualizaçăo teórica, situando o leitor em relaçăo aos fundamentos com os quais investigamos o texto. Na segunda, destacamos, dentre o que se tornou notícia na década de 1950 e foi publicado por O Progresso, um enunciado que aborda o assunto "migraçáo". Nele, encontramos posicionamentos acerca da situaçáo político-administrativa da Colônia Agrícola Nacional de Dourados e de seus atores sociais. As reflexóes discursivas aqui realizadas săo importantes à compreensăo do papel do "migrante" nas políticas expansionistas de colonizaçăo da época de 1950.

No próximo tópico, apresentamos alguns conceitos destacados de obras de Michel Foucault que mobilizamos para analisar uma matéria jornalística. Assumimos deliberadamente que o discurso jornalístico năo é, historicamente falando, o principal produto e o resultado terminal do funcionamento da instituiçāo mídia (RODRIGUES, 2002). Para este autor, "A mídia produz discursos como os pintores pintam telas, os músicos compóem músicas, os arquitetos projetam edifícios. É claro que a mídia desempenha também outras funçóes, mas todas elas têm no discurso o seu objetivo e a sua expressăo final". (RODRIGUES, 2002, p. 217). 


\section{DISCURSO JORNALÍSTICO: DIZERES SOBRE O MIGRANTE}

Falar de "migraçăo"é, em tempos contemporâneos, tratar de assunto proeminente em diversas esferas das sociedades capitalistas. Entender, portanto, como os sujeitos dizem o que dizem sobre o "migrante" (doravante, sem aspas) implica também lançar entendimentos de como os poderes, ao longo da história, engendram permanências e rupturas no modo de significar o outro. Acreditamos, por esses motivos, que Foucault tem muito a contribuir para reflexóes neste realizadas.

Michel Foucault defende năo ser fácil dizer uma novidade. Isso porque as relaçōes de poder que percorrem todas as esferas das sociedades fixam, também, as fronteiras do dizer. Para o filósofo, os discursos sāo produtivos, obedientes a certas condiçóes de sua possibilidade, de seu aparecimento histórico. Em síntese: "Nâo se pode falar em qualquer época de qualquer coisa; nâo é fácil dizer qualquer coisa que seja nova". (FOUCAULT, 2000a, p. 61); eis aí uma espécie de enunciado-mor de analistas de discurso, especialmente os da corrente foucaultiana. Ao mesmo tempo em que os indivíduos sofrem coerçôes para e ao dizer, a enunciaçâo que levou à emergência de um enunciado, por năo ser da ordem do repetível, torna o enunciado um acontecimento raro. E esse efeito de raridade faz com que o enunciado, embora possa ser repetido, náo permita os mesmos sentidos ao mudarem suas condiçóes de produçâo. Ao dizer, o que foi dito, foi dito por um sujeito livre, capaz de fazer escolhas diante de possibilidades linguístico-discursivas de seu tempo; a liberdade é, logo, uma forma de resistência ao poder (FOUCAULT, 1996). Para esse pensador francês, o sujeito é livre justamente porque ele pode "escapar", "deslocar-se"; sendo a resistência possível, portanto, quando há exercício de poder entre sujeitos livres (FOUCAULT, 1995).

Como campo de produçăo, reproduçăo e circulaçăo de discursos, o jornalismo opera com o objetivo de, ao mesmo tempo, apropriar-se de certas ideias e, ao difundi-las, construir "verdades" a respeito de certas "coisas". Assim, o jornal é aqui encarado como esfera privilegiada para se problematizarem as formas como, num determinado contexto sócio-histórico, sujeitos falam e constroem imagens mútuas (eu-do-outro; outro-do-eu). Pela observaçăo de um texto jornalístico, perguntamo-nos sobre o que dizem seus sujeitos, mas também a partir de qual realidade espaço-temporal estăo ditos de uma forma e nâo de outra. De modo específico, quando se diz sobre X (migrante, no caso deste artigo), quais as condiçóes de emergência do enunciado concreto?

O discurso nâo é, embora assumamos o sujeito como livre, a manifestaçâo plenamente consciente de "um sujeito que pensa, que conhece, e que diz" (FOUCAULT, 2000a, p. 61). Para se analisarem discursos, assim, precisamos destacar as regras ou, melhor, as práticas que fazem ganhar forma determinado objeto e năo outro:

As condiçōes para que apareça um objeto de discurso, as condiçōes históricas para que dele se possa "dizer alguma coisa" [...] essas condiçóes [...] săo numerosas e importantes. [...]. O objeto năo espera nos limbos a ordem que vai liberá-lo e permitirlhe que se encarne em uma visível e loquaz objetividade. [...]. [o objeto] existe sob as condiçōes positivas de um feixe complexo de relaçôes. (FOUCAULT, 2000a, p. 51). 
Quando nos propomos, portanto, realizar a análise de um periódico impresso-digitalizado, esperamos observar como ele difunde determinado acontecimento, como produz narrativas a respeito de algo que acabam por construí-lo aos olhos do leitor. Lembra Foucault que o objeto "năo preexiste a si mesmo" (2000a, p. 51). O que é dito e, por conseguinte, o que nâo é obedecem a um conjunto de relaçôes "estabelecidas entre instituiçōes, processos econômicos e sociais, formas de comportamentos, sistemas de normas, técnicas, tipos de classificaçăo, modos de caracterizaçăo" (p. 51), etc., e é sobre essas "relaçôes" que tratamos a seguir.

\section{MIGRAÇÃO EM DOURADOS PELO MIRANTE DE O PROGRESSO}

Em 25 de julho de 1954, ano IV, n. 169, o jornal O Progresso publica a matéria "A Colonia Agricola Nacional de Dourados através de um valioso relatório", reproduzindo informaçōes de um texto técnico assinado por Pedro Paulo de Medeiros e dirigido a Getúlio Vargas, à época Presidente da República brasileira. Esta matéria aparece na primeira capa dessa ediçâo do jornal (Figura 1), continua na página quatro, passa para a página 2 da ediçấo de número 170, publicada em primeiro de agosto daquele ano, e termina na ediçâo de número 171, uma semana depois. Ou seja, o jornal levou três ediçóes para começar e terminar de publicar o relatório. 
Figura 1 - Página do Jornal O Progresso, 25.07.1954

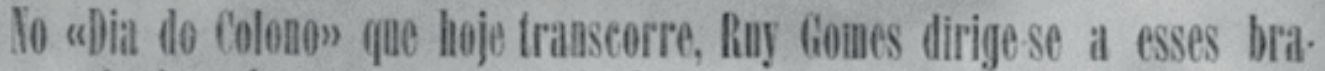
ros ohreiros do pregresso, rendendo-lhes inerecidia e sincera homenagem LAZZARO Allves Feppelpa Dispulará a vice-prefeitura na chapa da Alianca Democratica

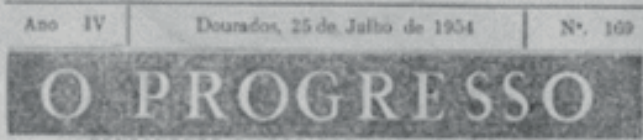

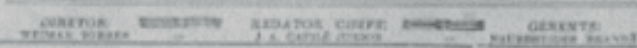

A Colonia Agricoia Necional de Dou. rados através de um valioso refatório

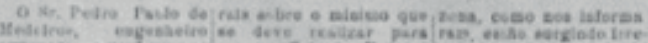

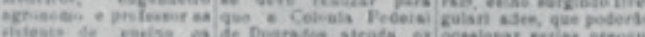

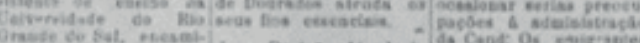

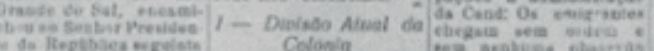

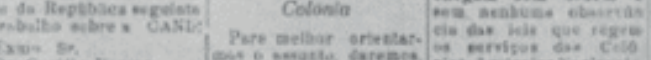
An vientio vare

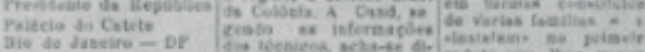

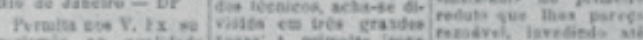

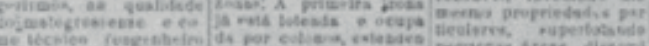

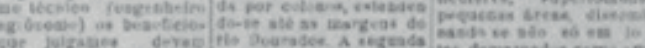

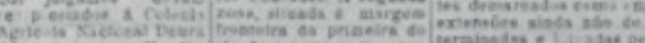

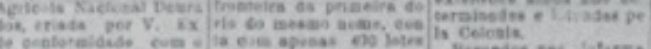

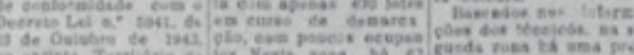

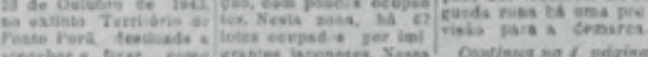

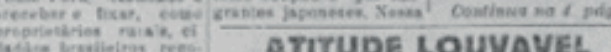

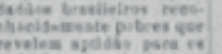
ATITUDE LOUVAVEL aioris rorresra

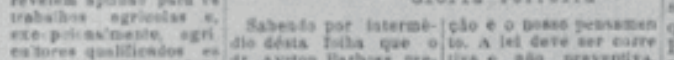

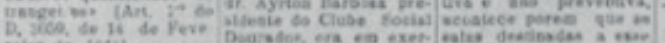

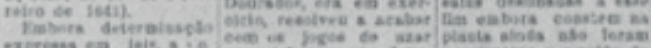

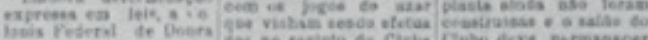

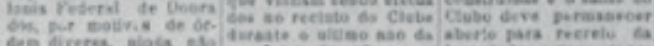

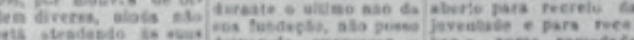

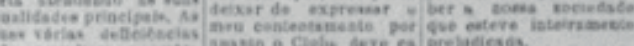

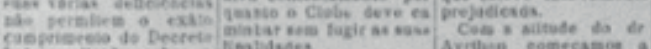

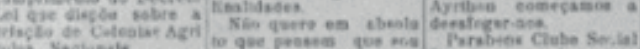

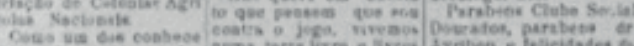

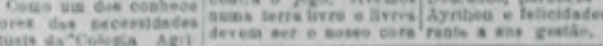
Pelo aumento do numero

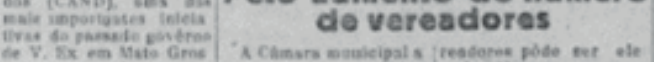

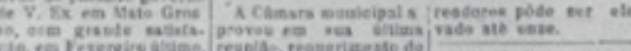

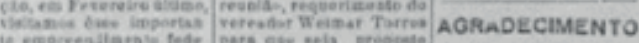

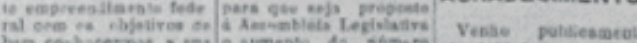

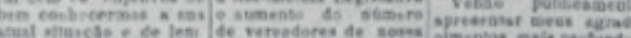

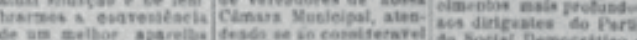

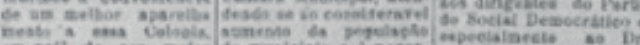

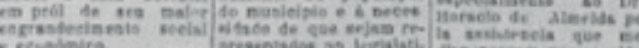

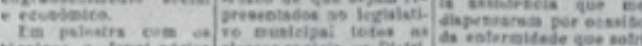

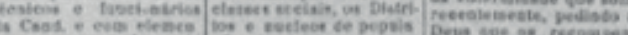

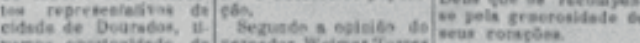

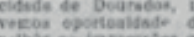

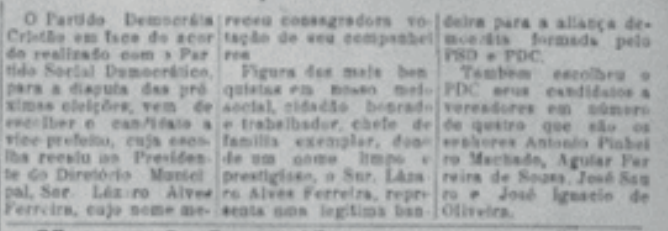

\section{Uma iniciativa exemplar}

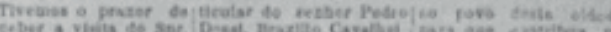

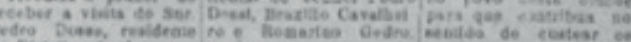

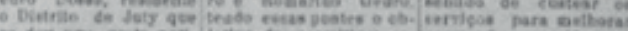

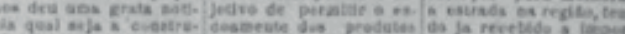

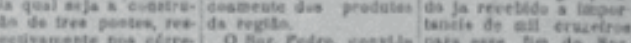

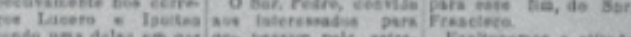

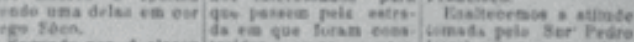

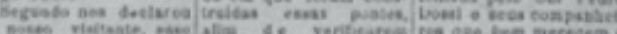

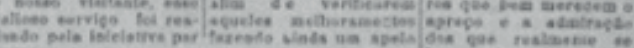
Souterio

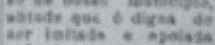

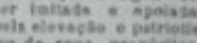
Coloora!

Nis passers do dis, emreridamete nosu. Desligamen. Desligamen.
to do P.S.P.

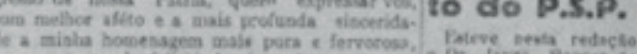

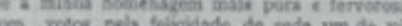

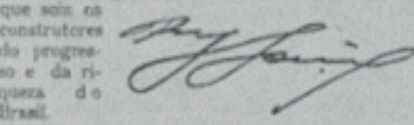

Prazo para inscriça e transferancias eleitorais

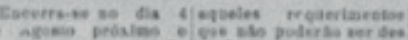

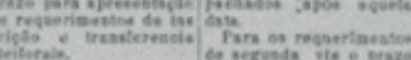

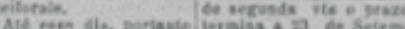

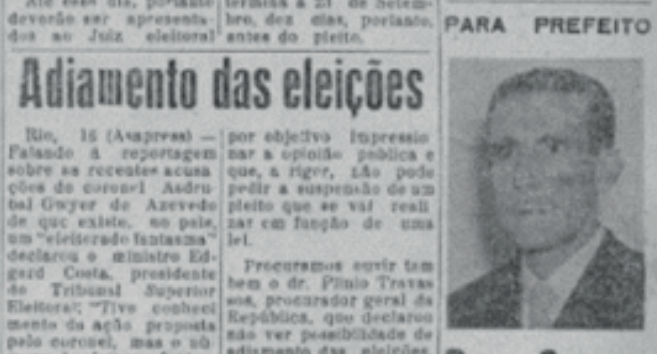

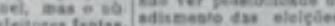

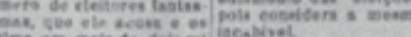

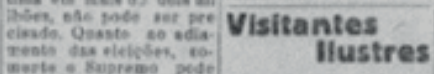

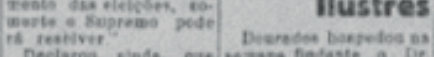

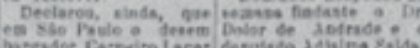

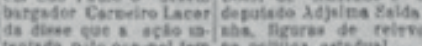
Ruy Gomes

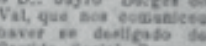
viliso seetsl Progres. as dirigita eticlo

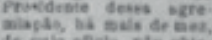

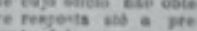
to

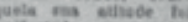
Gricetsd to exister purs polieanevile ecisio pios soo 00. PARA PREFEITO tas boaesta e prodativa Candidato PSD - PDC 
O texto assevera que reproduz integralmente um relatório de Pedro Paulo de Medeiros dirigido ao presidente Getúlio Vargas, exceto pelo lead, e faz parte de uma série de reportagens sobre o "Dia do Colono" reproduzidas pelo jornal, conforme ilustrado numa pequena nota, no meio da página, intitulada "Saudaçóes aos colonos", na qual se louva a importância desses sujeitos para o "progresso" do Brasil.

No primeiro parágrafo do texto-relatório, há a seguinte informaçăo:

[E1] O Sr. Pedro Paulo de Medeiros, engenheiro agrônomo e professor assistente de ensino da Universidade do Rio Grande do Sul, encaminhou ao Senhor Presidente da Repùblica, seguinte trabalho sobre a CAND.

E, logo em seguida, inicia com um endereçamento:

[E2] Exmo. Sr.

Dr. Getúlio Vargas

Presidente da República

Palácio do Catete

Rio de Janeiro - DF

Essas palavras iniciais nos permitem inferir que, após os dois pontos ([E1]: Enunciado 1), tudo o que se sucede é, ipsis litteris, fala de Medeiros. Ao trazer o nome completo do autor ao final da matéria, reforça-se ser este o autor do texto, logo, é imputada a ele, Medeiros, a responsabilidade pelo enunciado.

Ao buscar compreender como, a partir da materialidade efetiva dessa análise, sentidos sáo possíveis por este texto publicado pelo O Progresso e ao analisar a matéria jornalística como enunciado, estamos nos amparando em Foucault, para quem:

A análise dos enunciados se efetua, pois, sem referência a um cogito. Náo coloca a questăo de quem fala, se manifesta ou se oculta no que diz, quem exerce tomando a palavra sua liberdade soberana, ou se submete sem sabê-lo a coaçóes que percebe mal. Ela situa-se de fato, no nível de um "diz-se" - e isso náo deve ser entendido como uma espécie de opiniâo comum, de representaçáo coletiva que se imporia a todo indivíduo, nem como uma grande voz anônima que falaria necessariamente através dos discursos de cada um. (FOUCAULT, 2000a, p. 141, grifos do autor).

No trecho em questáo [E1], o enunciador atribui a responsabilidade pelo enunciado a um "engenheiro agrônomo", portanto, com conhecimento específico para tratar do assunto "colônia agrícola", e, ao mesmo tempo, "professor associado" de uma instituiçăo de ensino superior, no caso, a Universidade do Rio Grande do Sul, o que reforça ser este quem diz detentor de certo saber que o habilita a dizer. Aqui, logo, năo importa o indivíduo que disse, mas como a instituiçăo jornal constrói-lhe uma posiçăo viável, legítima para que possa dizer. No contexto, essa posiçâo discursiva é ocupada por um sujeito 
portador de condiçóes necessárias para poder produzir o enunciado, ainda mais, falar elegendo um interlocutor específico, conforme lemos no enunciado [E2]. Medeiros, neste tipo de enunciado, é o homem que tem as condiçôes de falar ao presidente.

Essa questăo elucida um posicionamento de Foucault, embora năo pensado por este autor para dar conta dos discursos da imprensa, para quem discursivamente náo importaria o indivíduo a partir do qual emanariam as frases, proposiçōes, atos de fala, e, sim, o sujeito que, em sua época, no seu espaço, é autorizado a dizer, a produzir enunciados. Para esse pensador francês, o discurso, em sua positividade, "nâo é uma consciência que vem alojar seu projeto na forma externa da linguagem; năo é uma língua, com um sujeito para falá-la. É uma prática que tem suas formas próprias de encadeamento e de sucessăo". (FOUCAULT, 2000a, p. 193). Em outro momento, esse filósofo reforça que há procedimentos de controle e de delimitaçăo do discurso: "Sabe-se bem que năo se tem o direito de dizer tudo, que năo se pode falar de tudo em qualquer circunstância, que qualquer um, enfim, náo pode falar de qualquer coisa" (FOUCAULT, 1996, p. 8-9).

Em E1, o sujeito-enunciador năo só é autorizado a falar, a falar de novo, pela instituiçâo jornal, como lhe săo reconhecidos, pelo próprio periódico, seus méritos para isso. Ao usar o adjetivo "valioso" no título, o jornal atribui destaque ao trabalho de Medeiros, posto que algo "valioso" é portador de valores eufóricos, portanto, nâo pode ser desprezado. O emprego, portanto, desse recurso linguístico contribui para, de início, criar uma espécie de empatia discursiva entre o texto (relatório) e o leitor (do jornal), reforçando o posicionamento assumido pelo enunciador conforme analisamos a seguir. A adjetivaçăo no título e as qualificaçôes profissionais atribuídas pelo jornal a Medeiros contribuem para criar um efeito de credibilidade ao texto e reforçam um efeito de realidade.

Em seguida ao endereçamento [E2], o texto traz uma afirmaçăo que reforça nossa leitura, quando o sujeito-enunciador assim se expressa:

[E3]: Permita nos V.Ex. sugerirmos, na qualidade do matogrossense e como técnico (engenheiro agrônomo) os benefícios que julgamos devam ser prestados á Colonia Agricola Nacional Dourados.

Manifesta năo só sua condiçấo de detentor de um saber e de uma profissâo, que lhe ratifica o ethos de autoridade, ou seja, ser engenheiro agrônomo, como também apresenta um elemento novo: ser um patrício, tal qual os leitores do jornal. Amossy, mobilizando uma fala de Bourdieu, destaca que "[...] o discurso náo pode ter autoridade se náo for pronunciado pela pessoa legitimada a pronunciá-lo em uma situaçâo legítima, portanto, diante dos receptores legítimos" (BOURDIEU apud AMOSSY, 2008, p. 120). Dizer tratar-se de um "matogrossense" impacta diferentemente quando se trata do leitor do jornal ou, considerando a finalidade primeira do texto, do Presidente da República. No primeiro caso, pode ocorrer um efeito de identificaçăo solidária para com o sujeito-enunciador; no segundo, de reconhecimento de certa causa. Essas duas informaçôes colocadas em conjunto criam, por um lado, um poderoso efeito de adesâo discursiva e, por outro, confere autoridade ao que está sendo dito, pois quem fala é alguém que tem profundo conhecimento da situaçăo da Colônia. 
Na sequência, após citar a lei n. 5941/1943, que institui juridicamente a CAND, menciona literalmente o artigo primeiro do decreto-lei n. 3050/1941, por estabelecer as normas de criaçăo das colônias agrícolas nacionais, cujo objetivo era "receber e fixar, como proprietários rurais, cidadăos brasileiros reconhecidamente pobres que revelem aptidăo para os trabalhos agrícolas e, excepcionalmente, agricultores qualificados estrangeiros" (MEDEIROS, 1954a, p. 1). Feita essa citaçăo, marcando a diferença entre "trabalhadores brasileiros" e "estrangeiros qualificados" (agricultores), observa o autor que, decorridos dois anos da publicaçâo do decreto referido, a colônia de Dourados ainda năo se efetivou por uma série de "deficiências", apresentadas e comentadas ao longo de seu texto.

Antes de discorrer a respeito dos problemas que impediram a realizaçăo plena da CAND, Medeiros reafirmar ser conhecedor dessa realidade: "Como um dos conhecedores das necessidades atuais da Colonia Agricola Nacional de Dourados [...]" (1954a, p. 1), e que, juntamente com técnicos, funcionários da CAND e representantes municipais, chegaram a dez constataçôes, que passamos a expor e analisar.

No primeiro item ("Divisâo atual da colônia"), após dizer como está dividida a colônia, afirma que, na "segunda zona", num total de 400 lotes, encontram-se "imigrantes japoneses", ocupantes de 62 lotes demarcados. Segundo foi-lhe informado, atribuindo autoria pela informaçăo ao genérico "técnicos", nessa última zona:

[E4]: [...] estăo surgindo irregula[d]ades, que poderăo ocasionar serias preocupaçóes à administraçăo da Cand: Os emigrantes chegam sem ordem e sem nenhuma observância das leis que regem os serviços das Colônias Agricolas Nacionais, em turmas constituídas e se "instalam" no primeiro reduto que lhes pareça razoável, invadindo até mesmo propriedades particulares, superlotando pequenas áreas, disseminando se náo só em lotes demarcados como em extensôes ainda nâo determinadas e lotadas pela Colonia. (MEDEIROS, 1954a, p. 1)

Logo no primeiro item, Medeiros faz referência ao migrante, nomeadamente, ao "japonês"3, significativamente o único que, ao longo do relatório em análise, recebe uma denominaçâo de origem. Para Medeiros, que atribui a responsabilidade pelas informaçōes a "técnicos", os emigrantes sâo classificados como desordenados ("chegam sem ordem") e desobedientes ("sem nenhuma observância das leis"). Para o sujeito-enunciador, esses migrantes săo "foras da lei" e, logo, precisavam ser enquadrados para que houvesse ordem na Colônia Agrícola. Há aí, portanto, os contornos de um discurso que, primeiro deslegitima o outro distante do eu (resistente, portanto), para depois, ao transformá-lo em um outro mais próximo do eu (obediente), louvá-lo.

Ainda hoje ecoa essa condiçâo de transgressor, desobediente, desordenado regularmente atribuída à figura do migrante e/ou do refugiado, como observamos neste enunciado recente:

3 Para uma compreensăo histórica da migraçáo japonesa para o sul de Mato Grosso, ver o trabalho de Edna Inagaki (2008). Sugerimos, para uma leitura mais histórica e abrangente, o trabalho de Resistência ఈ integraçâo: 100 anos de imigraçâo japonesa no Brasil, publicado pelo IBGE em 2008. Disponível em: http://biblioteca.ibge.gov.br/visualizacao/livros/liv38935.pdf. Acesso em: 24 jul. 2017. 
Muito do discurso da política migratória é maniqueísta e perverso. Baseia-se em estereótipos discriminatórios e tendenciosos, nos quais o migrante é visto como um transgressor da lei, enquanto deliberadamente se omite que ele seja um trabalhador explorado, sem benefícios, segurança social e sem direitos [...]. (RAMÍREZ, 2017, grifos nossos) ${ }^{4}$.

Em síntese, "a presença (física e/ou simbólica) do migrante coloca, por assim dizer, constantemente em xeque certo discurso da pureza, do qual esse "estrangeiro" seria a parte (a ser) aceita ou, conforme o caso, enfrentada, excluída, marginalizada, demonizada" (GOIS, 2016, p. 248). Esse "outro" (migrante, refugiado, portador de visto humanitário) sempre provoca fissuras na "compreensăo de unidade identitária nacional, regional ou mesmo local" presente no discurso do "eu".

No item 2, "Determinaçăo da área da Colonia", Medeiros traz informaçóes técnicas sobre o trabalho do engenheiro Paulo Thiry, responsável por demarcar as fronteiras dos 300 mil hectares destinados à CAND. Afirma o sujeito-enunciador tratar-se de tarefa difícil pois, além de faltar mâo de obra especializada e barata, problemas na mudança de administradores e de natureza (estradas inadequadas para resistir à estaçấo das chuvas; alagamento das regiôes a serem demarcadas; etc.) contribuíram para o retardamento do trabalho de estabelecimento dos limites dos lotes. Ao dar relevo à especializaçăo da mâo de obra e "barateza", o sujeito-enunciador reforça um discurso marcante no capitalismo colonial e que se demonstra atual na época do Relatório de Medeiros. Esse discurso, de que certos lugares precisam de máo de obra barata para o trabalho, pode ser assim sintetizado:

O importante năo é a existência de duas "sociedades", ou seja, de dois polos que contrastam entre si em termos de diversos índices socioeconômicos, senáo as relaçóes que existem entre esses dois "mundos". Enquanto o desenvolvimento localizado em algumas zonas da América Latina se baseia na utilizaçáo da máo de obra barata (náo é principalmente isto que atrai aos nossos países o capital estrangeiro?), as regióes atrasadas - que sáo provedoras dessa máo de obra barata - desempenham uma funçấo específica na sociedade nacional, e nâo sâo meramente áreas nas quais - por uma razăo ou outra - năo chegou o desenvolvimento. Ademais, essas áreas "arcaicas" săo geralmente exportadoras de matérias-primas, também baratas, para os centros urbanos e o exterior do país. (STAVENHAGEN, 2014, p. 161).

Na sequência ("Demarcaçâo de maior numero de lotes por ano"), Medeiros volta a comentar sobre a necessidade de rapidamente se estabelecerem os limites dos sítios destinados à Colônia. Isso para evitar a ilegalidade de "numerosos emigrantes, que penetram nas matas sem a determinaçăo do lote que deverá [sic] ocupar" (MEDEIROS, 1954b, p. 2.). Aponta o autor que essa "situaçăo" está provocando problemas à administraçăo da CAND, posto que famílias ocupam o mesmo lote, dificultando inclusive atendimento médico familiar. Nâo menciona, nominalmente, tratar-se do migrante

$4 \quad$ No original: “Mucho del discurso de la política migratoria es maniqueo y perverso. Se basa en estereotipos discriminatorios y tendenciosos, donde el migrante es visto como un transgresor de la ley, mientras deliberadamente se omite que es un trabajador explotado, carente de prestaciones, seguridad social y sin derechos [...]". Disponível em: http://www.alainet.org/es/articulo/184923. Acesso em: 20 jul. 2017. (traduçăo e grifos nossos). 
japonês, mas inferimos que esses atores estejam (também) imbricados na fala de Medeiros.

Uma das práticas que Medeiros considera um "problema" administrativo é o arrendamento: "os que conseguem lotes regularmente, arrendam nos (sic) aos que chegam em prejuízo, nâo raro, das atividades normais da Colônia" (1954b, p. 2). Para estabelecer certo ordenamento, o autor sugere ao Presidente da República que "o emigrante só fosse recebido na Colonia com o lote ou lotes determinados", pois isso facilitaria o trabalho dos administradores. E menciona, como fundamento, os artigos de 10 a 13 do Decreto-Lei n. 3059/19415.

A ideia de "ordem" (a necessidade de) é evocada por Medeiros para reforçar sua relaçăo com o "progresso" (desenvolvimento) da CAND e, consequentemente, da regiấo por uma perspectiva particular que é a do discurso capitalista colonial. A expressáo "ordem e progresso" está manifesta na bandeira brasileira e tem sido utilizada em vários enunciados de cunho (extremo)nacionalista. Destacada de outro conhecido enunciado de Augusto Comte, recebe de Ribeiro Junior a seguinte explicaçâo:

A fim de melhor guiar a vida real, esta fórmula universal [“O Amor por princípio, e a Ordem por base; o Progresso por fim"] do positivismo se decompóe em duas divisas usuais - uma moral e estética: "Viver para outrem", ou seja, subordinar o indivíduo à família, esta à pátria e a pátria à humanidade; e outra política e científica: “Ordem e Progresso", isto é, organizaçăo, cada coisa em seu devido lugar para perfeita orientaçăo ética da vida social. Na dialética positivista, o amor procura a ordem e a impele para o progresso; a ordem consolida o amor e dirige o progresso; o progresso desenvolve a ordem e reconduz o amor. (RIBEIRO JR, 2001, p. 29)

No texto de Medeiros, quando trata da administraçăo da CAND, a "divisa moral e estética" é apagada. Fazendo ecoar apenas sua dimensâo político-científica. Isso é compreensível se aceitarmos que, na lógica capitalista de desenvolvimento, o valor do ter se sobrepóe ao valor do ser. Retomamos essa questăo mais adiante.

5 Săo eles, na ortografia da época:

“Art. 10. Em cada lote será construída pequena casa para residência do colono e sua família, do tipo mais conveniente à regiăo.

Art. 11. Aprovado o plano geral de colonizaçâo e executados os respectivos trabalhos, será organizada a relaçăo dos candidatos aos lotes, dando-se preferência, na distribuiçấo, aos elementos locais e dentre estes os de prole numerosa assim considerados os chefes de família que tenham, no mínimo, cinco filhos menores que vivam sob a sua dependência.

Art. 12. Os lotes casas e quaisquer bemfeitorias nele existentes, serăo concedidos gratuitamente, observadas as seguintes condiçôes: a) o colono terá, o domínio útil do lote, nele residindo e recebendo, para a sua exploraçâo agrícola, sementes e material agrário mais urgente; b) de acordo com a regiăo e possibilidade de escoamento da produçấo agrícola para os centros de consumo, será marcado o prazo em que o lote deverá ser utilizado agriculamente em condiçôes satisfatórias de técnica e extensăo; c) findo o prazo a que, se refere o item anterior e preenchidas as demais condiçôes constantes deste decreto-lei, o colono receberá em plena propriedade o lote a casa e o material agrícola em seu poder, independentemente de qualquer pagamento.

Art. 13. Aos colonos serâo facultados os seguintes auxílios, a partir da data de sua localização no núcleo: 1) trabalho a salário ou empreitada em obras ou serviços da colônia, pelo menos durante o primeiro ano; 2) assistência médica e farmacêutica e serviços de enfermagem até a emancipaçáo de colônia; 3) empréstimo, durante o primeiro ano de localizaçăo na colônia de máquinas e instrumentos agrícolas e de animais de trabalho; 4) transporte da estaçăo ferroviária, porto marítimo ou fluvial até a sede da colônia". Disponível em: http://www.lexml.gov.br/urn/urn:lex:br:federal:decreto.lei:1941-02-14;3059. Acesso em: 24 jul. 2017. 
Em quatro ("Instalaçâo de maior número de escolas, Convenientemente aparelhadas, Para uma populaçăo estimada em 25 mil pessoas"), o autor discorre a respeito da necessidade de se construírem mais prédios para atender à demanda crescente (da populaçăo total, 1400 eram crianças em fase escolar). Nâo há mençăo ao migrante.

No próximo tópico ("Melhor Orientaçăo Agricola"), Medeiros, sem citar o migrante, trata da necessidade de construçâo da "Estaçăo Experimental ou campo de experimentaçăo e de Multiplicaçăo de Sementes e Mudas", cujo objetivo é, além de desenvolver o lado da agricultura, subsidiar os colonos com informaçôes para que sejam capazes de produzir "mais com menos gastos" (MEDEIROS, 1954b, p. 2). Nesse sentido, também seria papel dessa Estaçăo "desenvolver e incrementar a criaçăo de gado leiteiro, de suínos, de aves, de abelhas melíferas [...]" (p. 2).

O sétimo item ("Melhor aparelhamento da CAND") aborda a importância de se investir em maquinários e instalaçôes, acrescentando uma série de itens importantes, destinados a fazer estradas, processar madeira, perfurar poços, transportar pessoas pelo longo território, etc..

Na ediçâo de número 171, de 8 de agosto de 1954, o jornal O Progresso publica o final do relatório de Pedro Paulo de Medeiros. Nesse último trecho, o autor defende que o governo federal precisa dar "Amparo à produçăo (item 8)", à construçâo da "Sede da colônia Federal de Dourados" (item 9) e, por fim, à criaçáo de "Centro Recreativo" (item 10) destinado ao lazer dos colonos. E fecha seu texto dirigindo-se a Getúlio Vargas:

[E4]: Sr. Presidente Esperamos mereça as atençôes de V. Excia a nossa colaboraçăo para o maior engrandecimento da Colonia Agricola Nacional de Dourados, um dos grandes benefícios prestados por seu governo ao meu Estado natal, Mato Grosso.

Servidor e correligionário de V. Excia.

\section{PEDRO PAULO DE MEDEIROS}

Da leitura realizada, é possível depreender que o jornal O Progresso, ao publicar em suas páginas o relatório de Pedro Paulo de Medeiros dirigido ao entáo Presidente da República, Getúlio Vargas, objetiva năo apenas apresentar informaçóes ao leitor sobre a Colônia Agrícola Nacional de Dourados produzidas por um "engenheiro agrônomo" e "professor universitário"; tampouco criar somente um efeito de adesâo de seu público à causa levantada por Medeiros, um sujeito que, além de competente tecnicamente, é mato-grossense. O periódico quer reforçar certa perspectiva de sociedade que, para progredir, precisa de ordem. E, no mesmo processo, por se ancorar na fala de outrem (no caso, na do engenheiro Agrônomo Pedro Paulo Medeiros), năo ter responsabilidade total por aquilo que está sendo dito.

Para que a CAND seja economicamente viável, podemos, dos dez problemas identificados e suas soluçôes apontadas por Medeiros, reduzi-los a dois: a) diante das deficiências materiais da Colônia, o autor solicita ao governo federal que libere recursos para equipamentos, prédios, contrataçăo de máo de obra, etc.; b) diante dos problemas com migrantes, pede a delimitaçăo rápida das áreas para distribuí-las conforme determina a Lei. Esta serve, portanto, para impedir que esses sujeitos se 
instalem desordenadamente, conforme seus desejos e em qualquer área que lhes seja mais aprazível.

Esta última observaçăo carece de um refinamento. Numa primeira leitura, a questăo das "invasóes" por parte dos migrantes em espaços que năo lhes sâo próprios, destinados pelo sujeito estatal, parece ser uma questăo de legalidade, de afronta às leis, o que obrigaria os órgâos públicos competentes a cumprir a Lei e punir os infratores. Numa aproximaçăo mais cuidadosa, porém, vemos como Medeiros frequentemente chama a atençâo para a questâo da "administraçâo pública", e o enunciado [E3], dentre outros, reforça essa leitura. Para o autor, os problemas apontados por ele săo questóes administrativas, das deficiências estruturais e das atividades próprias da Colônia, e nâo penais.

Alguns fundamentos de Foucault, embora năo formulados para pensar o discurso da imprensa, săo mobilizados para compreendermos as razôes desse posicionamento de Medeiros. Para o filósofo francês, o exercício do poder se realiza, nas sociedades ocidentais modernas, na norma, e nâo mais na lei. Para ele, "[...] a norma traz consigo ao mesmo tempo um princípio de qualificaçăo e um princípio de correçăo. A norma năo tem por funçăo excluir, rejeitar" (FOUCAULT, 2001, p. 62). Em nenhuma parte do texto de Medeiros vemos uma manifesta chamada para o governo federal usar de seu aparelho repressor e punir o suposto "migrante criminoso". Pelo contrário, dirige-se ao Presidente da República para que este disponibilize os recursos necessários para garantir que o "migrante" se torne "colono" e, desse modo, possa produzir "mais com menos gastos" (mâo de obra barata), conforme demonstramos. Quando consideramos a norma como estando "sempre ligada a uma técnica positiva de intervençâo e de transformaçăo, a uma espécie de poder normativo" (FOUCAULT, 2001, p.62), percebemos no discurso de Medeiros esse poder normalizador em (dis)curso.

A Colônia é construída, assim, como um espaço onde se busca regular a vida dos indivíduos e das populaçóes (FOUCAULT, 2000b, 2001, 2008); um lugar para controlar o corpo dócil; um lugar para a objetificaçăo do outro. Obedecer às leis, por fim, assim como manter-se disciplinado, săo duas formas do processo que Foucault chama "disciplina-normalizaçăo": "um poder que, na verdade, nâo é repressivo, mas produtivo" (FOUCAULT, 2001, p. 64). Busca, esse poder, uniformizar os sujeitos e seus comportamentos para serem ordenados para uma certa lógica de progresso.

A ideia de "colônia agrícola" de Medeiros reforça, portanto, a dimensâo estrutural-predial (ter), e pouco dedica-se às pessoas (migrantes ou nâo), ao ser, portanto, que estăo envolvidas com a CAND. Há, desse modo, um reforço/apelo por parte do sujeito- enunciador pela objetificaçâo do processo, e năo por sua subjetificaçâo, mesmo quando fala em construir escolas para as crianças; prédios para a populaçăo; área de lazer para os colonos. E há uma explicaçăo razoável para esse tipo lógica que funda essa prática discursiva, e ela remonta ao século 18 e continua produtiva na época de Medeiros e, ao que tudo indica, ainda hoje. Essa lógica pode ser assim resumida: “O desenvolvimento deste sistema econômico [o capitalismo do século XVIII] nâo era já determinado pela pergunta: $O$ que é bom para o Homem? Mas por uma outra: O que é bom para o crescimento do sistema?" (FROMM, 1987, p. 78). Em outros termos, no relatório em análise, o bom para a CAND está centrado no ter (normas, prédios, escolas, estradas, etc.), e nâo no ser. O ser ocupa, no relatório, uma posiçăo secundária, completamente subalterna ao ter. 
Por fim, Medeiros insiste, ao longo de seu relato dirigido a Getúlio Vargas, na buscar por meios para, em última instância, estabelecer normas basilares para o funcionamento "normal" dos indivíduos e das populaçōes, aos quais se tenta administrar. Como acentua Portocarrero: "A normalizaçăo [...] constrange para homogeneizar as multiplicidades, ao mesmo tempo que individualiza, porque permite a distância entre os indivíduos" (2009, p. 241). E o jornal O Progresso, ao reproduzir a carta de Medeiros, acaba por contribuir, em outra esfera, para que esse discurso da normalizaçăo se efetive. Essa observaçăo de Portocarreto permite-nos inferir que o texto de Medeiros é uma das práticas que buscam transformar o "migrante" (japoneses, nordestinos, paulistas, etc.) em "colono" (colono mato-grossense), conforme já mencionamos. Ademais, no caso dos primeiros, havia, por parte do governo brasileiro, toda uma política de imigraçâo contrária a vinda de japoneses e, outros orientais de maneira em geral, ao Brasil. Essa política partia da infeliz ideia de que o povo brasileiro precisava ser embranquecido. Desse modo, legitimar-se-ia năo apenas o poder estatal sobre a Colônia Agrícola Nacional de Dourados, mas, fundamentalmente, se exerceria mais facilmente o controle da populaçâo.

\section{NOTAS DE CONCLUSÃO}

O objetivo central deste artigo foi mostrar como, por meio da leitura de um jornal regional da década de 1950, é possível identificar traços linguístico-discursivos e histórico-sociais que, ainda hoje, permitem-nos compreender nossas sociedades contemporâneas capitalista. Para tanto, procedemos à análise de um texto publicado em 1954 no jornal O Progresso, intitulado "A colônia agrícola nacional de Dourados através de valioso relatório", assinado por Pedro Paulo de Medeiros.

O jornal O Progresso encarrega-se de mostrar como, no ano de 1954, numa cidade emergente do sul do entăo Mato Grosso, via-se e compreendia-se a relaçấo entre a Colônia Agrícola Nacional de Dourados e seus atores sociais: colonos e migrantes. Neste último caso, importa destacar certo papel que o sujeito-enunciador dá para o migrante, apresentando um conjunto de normas e procedimentos a que este sujeito deve se submeter para se tornar um colono.

Buscarmos compreender, por fim, como o "migrante" é construído, objetificado neste relatório quando da solidificaçăo da CAND. Essa objetificaçâo do migrante produz eco ainda hoje tanto de cá quanto de lá do Atlântico. E tal posiçăo nos faz lembrar Paul Veyne (1998), para quem as sociedades sâo o que săo por causa de sujeitos que, numa relaçăo sempre (in)tensa entre poder e resistência, vấo edificando os muros de nossa existência ao longo da história. 


\section{REFERÊNCIAS}

AMOSSY, Ruth (Org.). Imagens de si no discurso: a construçăo do ethos. Săo Paulo: Editora Contexto, 2008.

CARLI, Maria A.F. Dourados e a democratizaçâo da terra: Povoamento e colonizaçấo da Colônia Agrícola Municipal de Dourados (1946-1956). Dourados: UFGD, 2008. IBGE. Resistência ఈ integraçâo: 100 anos de imigraçâa japonesa no Brasil. Rio de Janeiro: IBGE, 2008. (Centro de Documentaçăo e Disseminaçâo de Informaçôes.)

ERNANDES, Mercolis Alexandre. A construçâo da identidade douradense: 1920 a 1990. Dourados: UFGD, 2009.

FOUCAULT, Michel. O sujeito e o poder. In: DREYFUS, H; RABINOW, P. Michel Foucault, uma trajetória filosófica - para além do estruturalismo e da hermenêutica. Traduçăo Vera Porto Carrero. Rio de Janeiro: Forense Universitária, 1995.

FOUCAULT, Michel. A ordem do discurso. Traduçāo Laura Fraga de Almeida Sampaio. Sáo Paulo, Loyola, 1996.

FOUCAULT, Michel. A arqueologia do saber. Traduçăo Luiz Felipe Baeta Neves. Rio de Janeiro: Forense Universitária, 2000a.

FOUCAULT, Michel. Em defesa da sociedade: Curso no Collège de France (1975-1976). Traduçâo Maria Ermantina Galvâo. Sáo Paulo: Martins Fontes, 2000b.

FOUCAULT, Michel. Os anormais: Curso no Collège de France (1974 - 1975). Traduçāo Eduardo Brandăo. Săo Paulo: Martins Fontes, 2001.

FOUCAULT, Michel. Segurança, território, populaçâo: curso dado no Collège de France (1977-1978). Traduçăo Eduardo Brandăo. Săo Paulo: Martins Fontes, 2008.

FROMM, Erich. Ter ou Ser?. Traduçăo Nathanael C. Caixeiro. 4. ed. Rio de Janeiro: Zahar, 1987.

GÓIS, Marcos L.S. Discursos contemporâneos: migrantes haitianos no jornal O Globo. IN: GUERRA, Vânia M. L.; NASCIMENTO, Celina A. G. S.; SOUZA, Claudete C.. (Org.). Sociedades contemporâneas: diversidade e transdisciplinaridade. 1ed.Campinas - SP: Pontes, 2016. p. 241-270.

INAGAKI, Edna M. Migraçăo japonesa para o Brasil: os japoneses em Dourados (séculos XIX e XX). Dourados, MS: Ed. UEMS, 2008. 97p. 
JARDIM, Denise. Imigrantes ou Refugiados?: tecnologias de controle e as fronteiras. Jundiaí, SP: Paco, 2017.

MEDEIROS, Pedro Paulo. A colônia agrícola nacional de Dourados através de valioso relatório. O Progresso. Dourados, MS, p. 1 e 4, 25 jul. 1954a.

MEDEIROS, Pedro Paulo. A colônia agrícola nacional de Dourados através de valioso relatório (continuaçăo 2). O Progresso. Dourados, MS, p. 2, 1 ago. 1954b.

MEDEIROS, Pedro Paulo. A colônia agrícola nacional de Dourados através de valioso relatório (continuaçâo 3). O Progresso. Dourados, MS, p. 2, 8 ago. 1954c.

NAGLIS, Suzana G. B. "Marquei aquele lugar com o suor do meu rosto": os colonos da Colônia Agrícola Nacional de Dourados - CAND (1943 - 1960). Dourados-MS: UFGD, 2014.

OLIVEIRA, Benícia Couto de. A política de colonizaçâo do Estado Novo em Mato Grosso (1937-1945). 1999. Dissertaçăo (Mestrado em História) Faculdade de Ciências e Letras, Universidade Estadual Paulista, Assis, p. 128. PORTOCARRERO, Vera. As ciências da vida: de Canguilhem a Foucault. Rio de Janeiro: Editora Fiocruz, 2009.

RIBEIRO JR, Joâo. O que é positivismo. Săo Paulo: Brasiliense, 2001. (Coleçăo primeiros passos; 72).

RODRIGUES, Adriano Duarte. Delimitaçăo, natureza e funçōes do discurso midiático. In: MOUILLAUD, Maurice; PORTO, Sérgio Dayrell (org.). O Jornal: da forma ao sentido. 2. ed. Brasília: Editora Universidade de Brasília, 2002.

STAVENHAGEN, Rodolfo. Sete teses equivocadas sobre América Latina. Sociedade e Cultura, v. 17, n. 1, enero-junio, 2014, pp. 159-169. Disponível em: http://www.redalyc. org/articulo.oa?id=70340850015. Acesso em: 05 jan. 2018.

VEYNE, Paul. Foucault revoluciona a história. In. Como se escreve a história e Foucault revoluciona a história. Traduçâo Alda Baltar e Maria Auxiliadora Kneipp. Revisâo técnica Gerusa Jenner Rosas. 4. ed. Brasília, DF: Editora da UnB, 1998. 